\title{
First report of Septotinia populiperda on potato tubers in Russia
}

\author{
Elena M. Chudinova ${ }^{1} \cdot$ Sergey N. Elansky ${ }^{1,2}$ (-) \\ Received: 12 July 2020 / Accepted: 18 January 2021 / Published online: 29 January 2021 \\ (c) Società Italiana di Patologia Vegetale (S.I.Pa.V.) 2021
}

Keywords Potato diseases $\cdot$ Potato tuber $\cdot$ Septotinia populiperda $\cdot$ Wound parasite

In April 2018, seed potato tubers (cultivar Fantasia) with necrotic lesions were collected for analysis from the storage unit in the Moscow region of Russia, after appropriate permissions were obtained. Three tubers from a lot of 200 tubers with a cavity covered with black sclerotia were found. Axenic fungal culture was isolated from a sclerotium placed on $1.5 \%$ PDA amended with benzylpenicillin sodium $(1000 \mathrm{U} / \mathrm{ml})$. After 4 days at $25^{\circ} \mathrm{C}$ in a $16 / 8$ light/ dark cycle the fungus formed a white-gray mycelium; after 14 days it formed abundant black sclerotia.

Absence of sporulation and other specific fungal structures disqualified the morphological criteria for initial identification. DNA was isolated and sequenced as described in Kutuzova et al. (2017). The ITS1-5.8S-ITS2 rDNA region with primers ITS4/5, the 28S LSU rRNA with primers NL1/NL4, and the TEF1 $\alpha$ gene with primers EF1-728F / EF1-986R were amplified and sequenced. The ITS1-5,8SITS2 rDNA and 28S LSU rRNA sequences (GenBank accession Nos. MT672566, MT672567) had 97.95-100\% similarity to Septotinia populiperda Waterman \& E.K. Cash ex B. Sutton (=Septotis populiperda (Moesz \& Smarods) B. Sutton) (CBS 374.64, CBS 339.53, CBS 338.53, MH857234, MH101504, MH857235, MH101506, MH101507). Our sequence of the S. populiperda TEF1 $\alpha$ (MT675287) is the first submitted to GenBank NCBI. This fungus is known as a pathogen of Populus and Salix leaves (Sutton 1980; Zhu et al. 2019).

For pathogenicity testing, $5 \mathrm{~mm}$ agar discs with 7-dayold S. populiperda culture were used to inoculate 7 potato tuber slices and 7 whole intact tubers, which were then

Sergey N. Elansky

snelansky@gmail.com

1 Peoples Friendship University of Russia (RUDN University), Moscow 117198, Russia

2 Lomonosov Moscow State University, Moscow 119991, Russia incubated in wet chambers (closed plastic boxes with wet filter paper at the bottom) at $25^{\circ} \mathrm{C}$ in a $16 / 8$ light/dark cycle. As a control, 7 tuber slices and 7 whole tubers were inoculated with sterile agar discs. Five days after inoculation, lesions $10-15 \mathrm{~mm}$ in diameter appeared on the inoculated tuber slices. The controls were symptomless. S. populiperda was re-isolated from the inoculated tuber slices. Whole intact potato tubers were not infected. The fungus is apparently a wound parasite. To our knowledge, this is the first report of S. populiperda on potato tubers.

Funding This study was funded by the Russian Foundation for Basic Research (grant № 20-016-00139).

\section{Declarations}

Ethical approval This article does not contain any studies with human participants or animals performed by any of the authors.

Conflict of Interest Authors declare that they have no conflict of interest.

\section{References}

Kutuzova IA, Kokaeva LY, Pobedinskaya MA, Krutyakov YA, Scolotneva ES, Chudinova EM, Elansky SN (2017) Resistance of Helminthosporium solani strains to the fungicides applied for tuber treatment. J Plant Pathol 99:635-642. https://doi. org/10.4454/jpp.v99i3.3950

Sutton BC (1980) Septotinia and Septotis. Mycologia 72:208-213

Zhu LH, Xu W, Yang JY, Li DW, Ge JM, Ye JR (2019) First Report of Septotinia populiperda Causing Leaf Blotch of Salix babylonica in China. Plant Dis 103:768. https://doi.org/10.1094/PDIS-05-18-0827-PDN 